University of Nebraska - Lincoln

DigitalCommons@University of Nebraska - Lincoln

Agronomy \& Horticulture -- Faculty Publications

Agronomy and Horticulture Department

2013

Characterization of fluorescent Pseudomonas spp. associated with roots and soil of two sorghum genotypes

Deanna L. Funnell-Harris

USDA-ARS, Deanna.Funnell-Harris@ars.usda.gov

Scott E. Sattler

USDA-ARS, Scott.Sattler@ars.usda.gov

Jeffrey F. Pedersen

USDA-ARS, jpedersen1@unl.edu

Follow this and additional works at: https://digitalcommons.unl.edu/agronomyfacpub

Funnell-Harris, Deanna L.; Sattler, Scott E.; and Pedersen, Jeffrey F., "Characterization of fluorescent Pseudomonas spp. associated with roots and soil of two sorghum genotypes" (2013). Agronomy \& Horticulture -- Faculty Publications. 689.

https://digitalcommons.unl.edu/agronomyfacpub/689

This Article is brought to you for free and open access by the Agronomy and Horticulture Department at DigitalCommons@University of Nebraska - Lincoln. It has been accepted for inclusion in Agronomy \& Horticulture -Faculty Publications by an authorized administrator of DigitalCommons@University of Nebraska - Lincoln. 


\title{
Characterization of fluorescent Pseudomonas spp. associated with roots and soil of two sorghum genotypes
}

\author{
Deanna L. Funnell-Harris • Scott E. Sattler • \\ Jeffrey F. Pedersen
}

Accepted: 17 January 2013 /Published online: 30 January 2013

(C) US Government 2013

\begin{abstract}
Sorghum is used as bioenergy feedstock, animal feed, and food. Economical methods for disease prevention and control are valuable for producers. Fluorescent Pseudomonas spp. were isolated from sorghum roots and surrounding soil with the goal of finding isolates that significantly inhibited sorghum fungal pathogens. Fluorescent pseudomonads were collected from seedlings of sorghum cultivars RTx433 and Redlan and wheat cultivar Lewjain, grown in two soils. Lewjain is known to support growth of producers of the antibiotic, 2,4-diacetylphloroglucinol (2,4-DAPG). Isolates from all three plants were assessed for hydrogen cyanide $(\mathrm{HCN})$ and extracellular protease production, and for a 2,4-DAPG gene, phlD. Both soil type and plant type affected $\mathrm{HCN}$ - and protease-production, but $p h l D$ was not affected. Subsets of $p h l D^{+}$isolates were chosen to determine phlD genotypes and to conduct in
\end{abstract}

D. L. Funnell-Harris $(\bowtie)$

Grain, Forage and Bioenergy Research Unit,

Department of Plant Pathology,

USDA-ARS and University of Nebraska,

Lincoln, NE 68583-0937, USA

e-mail: Deanna.Funnell-Harris@ars.usda.gov

S. E. Sattler · J. F. Pedersen

Grain, Forage and Bioenergy Research Unit,

Department of Agronomy and Horticulture,

USDA-ARS and University of Nebraska,

Lincoln, NE 68583-0937, USA

S. E. Sattler

e-mail: Scott.Sattler@ars.usda.gov

J. F. Pedersen

e-mail: jpedersen3@neb.rr.com vitro inhibition assays against sorghum pathogens. Most isolates from sorghum and wheat were genotype D, previously associated with superior root colonization. $p h l D^{+}$sorghum isolates were co-cultured with five sorghum pathogens. One isolate from each sorghum line exhibited inhibition to all five pathogens but more Redlan isolates were inhibitory to the virulent pathogen, Fusarium thapsinum, than RTx433 isolates. Nearly all inhibitory isolates from either sorghum cultivar were from one soil type. This is consistent with what had been previously observed in field studies: that soil type played a significant role in determining characteristics of fluorescent Pseudomonas spp. isolated from roots or soil, but sorghum genotype also had a considerable effect.

Keywords 2,4-diacetylphloroglucinol $\cdot$ Fusarium thapsinum - Plant genotype - Soil type · Rhizobacteria . Sorghum bicolor (L.) Moench

\author{
Abbreviations \\ 2,4-DAPG 2,4-diacetylphloroglucinol \\ FIA Fungal inhibition assay \\ PDA Potato dextrose agar \\ phlD 2,4-diacetylphloroglucinol \\ biosynthetic gene
}

\section{Introduction}

Sorghum [Sorghum bicolor (L.) Moench] is fifth among six principal cereal crops in the world. In the United States, the grain is important for livestock and 
poultry feed, but it is a food staple in large portions of semi-arid tropical Africa and Asia. Food-grade sorghum is also utilized throughout the world because it is gluten-free, and contains a high concentration of beneficial phytochemicals (Asif et al. 2010). The grain, fodder (leaves and stalks from grain or forage sorghum) or juice (from sweet sorghum) can serve as feedstock for bioenergy production (Sarath et al. 2008). As well as being versatile, this $C_{4}$ crop is drought and heat tolerant, and therefore can be grown under marginal rainfall conditions without irrigation (Dogget 1988). Because of the value of sorghum for bioenergy feedstock and animal feed, and a food staple in cultures worldwide, it is important to identify practical and low cost methods for prevention and control of diseases.

Different plant genotypes can affect populations of rhizobacteria or other microorganisms that are antagonistic to soil-borne pathogens (Cook 2007). In contrast to well-studied crops such as wheat or flax, that are often grown in continuous monoculture season upon season, sorghum production often occurs in rotation cropping systems (Dogget 1988). Whether some sorghum genotypes induce the growth of beneficial Pseudomonas spp. that help protect sorghum against pathogens within a single season, remains to be determined. The use of such genotypes would ameliorate or prevent seedling, root, crown, or stalk diseases, and their possible effects on grain yield and quality. Fungal pathogens in the genus Fusarium spp. can infect sorghum at several stages of development causing seedling infection, stalk rot or grain mold disease, (Williams and Rao 1978). Curvularia lunata (Wakker) Boedijn 1933 and Alternaria alternata (Fr.) Keissl. 1912 also cause grain mold disease, while Macrophomina phaseolina (Tassi) Goid. 1947 causes charcoal rot of stalks primarily in drought-stressed plants (Williams and Rao 1978).

Rhizosphere-inhabiting fluorescent Pseudomonas spp. have been shown to produce compounds antagonistic to rhizosphere or soil-inhabiting pathogens. For example, suppression of wheat take-all disease is associated with a shift in wheat rhizosphere bacterial populations such that Pseudomonas spp. producing the antibiotic 2,4-diacetylphloroglucinol (2,4-DAPG) dominate (Raaijmakers and Weller 2001). Pseudomonas spp. have other mechanisms to enhance inhibition of soil fungi such as production of hydrogen cyanide ( $\mathrm{HCN})$ (Laville et al. 1992), or extracellular proteases (Anderson et al. 2004). Expression of genes contributing to biological control traits, such as production of antagonistic secondary metabolites, persistence in soil, or superior root colonization, involves global regulators that enable response to environmental changes (Weller 2007).

Previously, fluorescent Pseudomonas spp. isolated from soil during cycling of sorghum seedlings in crop sequences with wheat, and from roots and soil from field-grown plants during the growing season, were characterized for $\mathrm{HCN}$ and protease production and for genes for antibiotic production (2,4-DAPG and phenazine) (Funnell-Harris et al. 2008, 2010). Sorghum genotypes Redlan and RTx433 appeared to affect Pseudomonas spp. but these affects were strongly mitigated by environmental factors such as crop sequence, soil type or irrigation (Funnell-Harris et al. 2008, 2010). Redlan and RTx433 seedlings maintained rhizosphere populations of two rifampicin-marked Pseudomonas biocontrol strains from wheat, at levels similar to the wheat cultivar, Lewjain (Funnell-Harris et al. 2008). Taken together, these results indicate that sorghum genotypes may affect the selection and persistence of Pseudomonas spp., which have the potential to ameliorate sorghum diseases. In the present study, the following two hypotheses were tested. First, sorghum genotype influenced traits of fluorescent Pseudomonas genotypes found in rhizospheres or soil. Second, fluorescent Pseudomonas spp. isolated from sorghum roots or soil could significantly inhibit fungal pathogens of sorghum.

\section{Materials and methods}

Growth chamber sorghum and wheat seedling cycling

Cycling of sorghum and wheat seedlings was conducted as previously described (Funnell-Harris et al. 2010). Sorghum grain of cultivars Redlan and RTx433 were produced in greenhouses at University of Nebraska, Lincoln (UNL). Grain of wheat cultivar Lewjain was obtained from K. Garland-Campbell (USDA-ARS, Pullman, WA). Redlan and RTx433 were chosen for this study because they were previously shown to differ in root exudation among 25 elite sorghum lines, based on in vitro assays (Nimbal et al. 1996). Lewjain was chosen because previous work indicated that it supported growth of 2-4-DAPG fluorescent Pseudomonas spp. (Mazzola et al. 2004). 
Soil used was collected from post-harvest sorghum plots at UNL research fields at Lincoln (2008) and Ithaca (2007), NE, as previously described (FunnellHarris et al. 2010). Soil at Lincoln was a Kennebec silt loam, a fine-silty, mixed, superactive, mesic Cumulic Hapladolls. Fields at Lincoln were not irrigated. Soil at Ithaca was a Tomek silt loam, a fine, smectitic, mesic Pachic Ariguidolls and the fields were irrigated. The field at Lincoln had the following cropping sequence prior to planting sorghum in 2008: sorghum and soybean rotation from 2000 to 2005, then maize (2006) and soybean (2007). The field at Ithaca had the following cropping sequence prior to planting sorghum in 2007: oats (2000) then wheat (2001) followed by soybeans and sorghum in rotation.

To start cycling, 28 Ray Leach Cone-tainers ${ }^{\mathrm{TM}}$ (Stuewe \& Sons, Inc., Corvalis, OR) were planted with each of two sorghum genotypes, Redlan and RTx433, and wheat cultivar, Lewjain. Following planting, 10 to $15 \mathrm{ml}$ of one-third-strength Hoagland's solution lacking minerals, prepared in sterile filter-purified water (Labconco, Kansas City, MO), was applied to each Cone-tainer. Seedlings were grown for 4 weeks in a growth chamber, $22{ }^{\circ} \mathrm{C}$ with $12 \mathrm{~h}$ light, with 10 - to 15 $\mathrm{ml}$ applications of sterile filter-purified water three times per week. At the end of 4 weeks (cycle 1), seven randomly-chosen plants of each genotype were harvested. Roots, which included adhering soil, were aseptically snipped into $1-\mathrm{cm}$ pieces and a $1-\mathrm{g}$ sample from each plant was analyzed, as well as two 1-g soil samples from each Cone-tainer. For the remaining Cone-tainers, aerial plant parts were removed. Soils from Cone-tainers with the same sorghum genotype, or wheat, were combined in a surface-sterilized tub, mixed, and replaced into the same Cone-tainers, which were planted with the same sorghum genotype or wheat (cycle 2). The process was repeated until four cycles were completed. Two repetitions of the experiment were conducted. The first repetition, using soil collected from Ithaca, NE, consisted of four 4-week cycles, with seven replicate Cone-tainers for each treatment (Redlan, RTx433 or Lewjain), per cycle. The second repetition was conducted similarly except using soil collected at Lincoln, NE.

Prior to planting the experiment (soil samples from bulk soil), and at the end of each cycle (root and soil samples from each plant), numbers of fluorescent Pseudomonas spp. were determined as described in a previous publication (Funnell-Harris et al. 2010).
Briefly, soil or root samples were suspended in sterile filter-purified water and dilutions were prepared in sterile filter-purified water. For each Cone-tainer, $1 \mathrm{~g}$ fresh weight of roots (if available) were suspended and diluted and three aliquots were plated from each dilution. Two soil samples were also taken and individually suspended and diluted and one aliquot was plated from each dilution. Aliquots from root- or soil-suspensions were spread onto King's B agar medium (KB) amended with ampicillin $\left(100 \mathrm{\mu gml}^{-1}\right)$, cyclohexamide $\left(100 \mu \mathrm{gml}^{-1}\right)$ and chloramphenicol $\left(13 \mu \mathrm{gml}^{-1}\right)\left(\mathrm{KB}^{+}\right)$. Antibiotics were purchased from Sigma Aldrich (SA; St. Louis, MO). Fluorescing colonies, as determined using UV light, were counted and fluorescent Pseudomonas spp. colony forming units (cfu) per gram of fresh soil or roots was determined for each plant. Numbers of Pseudomonas isolates (cfu) per gram soil collected at Ithaca, NE during 2007, and cfu per gram roots or soil during cycling, were previously used in analyses in Funnell-Harris et al. 2010.

For each cone, up to 10 (Ithaca soil) or 15 (Lincoln soil) Pseudomonas isolates were collected from root and soil dilution plates. If isolates recovered were numerous, then isolates were randomly chosen from dilution plates; otherwise, all single colonies were transferred to $\mathrm{KB}$ agar medium for further analyses. Over 1,800 root isolates and 1,700 soil isolates were analyzed for the presence of the phlD gene and for extracellular protease activity using previously-described protocols (FunnellHarris et al. 2010). The isolates also were analyzed for $\mathrm{HCN}$ production. To detect $\mathrm{HCN}$, a previouslydescribed protocol (Funnell-Harris et al. 2008), or a modification of this protocol, was used. For the modified protocol, HCN screens were conducted in 48-well plates (Costar plate 3548, Corning Incorporated, Corning, NY). Each well was filled with $1 \mathrm{ml}$ of $2 \%$ peptone [Becton, Dickinson and Co. (BD), Sparks, MD, USA] agar. Whatman 3MM Chr blotting paper (Whatman International, Ltd., Maidstone, GB), cut to fit under the plate lid, was applied with detection reagent (0.025 g copper (II) ethylacetoacetate, $0.025 \mathrm{~g} \mathrm{4,4}$ ' methylene bis, and $10 \mathrm{ml}$ chloroform; Castric and Castric 1983) and dried. For each Pseudomonas isolate, small amounts of bacteria ( $1 \mathrm{~mm}$ diameter) from a 48 - to 72-h KB agar culture was transferred to the center of agar medium in three wells. The treated blotting paper was placed over the wells and the plate was covered with the lid then incubated at $35^{\circ} \mathrm{C}$ for $3 \mathrm{~h}$. The positive control, Pseudomonas protegens isolate, NRRL B23932 [also known as "Pf-5," formerly identified as 
Pseudomonas fluorescens (Ramette et al. 2011)] (USDA-ARS, National Center for Agricultural Utilization Research (NCAUR), Peoria, IL), was included, in triplicate, on each plate. Discolouration of the blotting paper above the well indicated HCN production.

Statistical analyses for numbers of fluorescent Pseudomonas spp. were conducted using the PROC GLIMMIX procedure of SAS/STAT software ${ }^{\circledR}{ }^{1}$ (SAS 2002-2008). In the model statement, the DIST = GAMMA option was used to specify a gamma probability distribution, because the data were not normally distributed, and the LINK = LOG option was used to specify the link function. In the LSMEANS statement of the model statement, the ILINK option was used to calculate least squares means (LSM) and standard errors (SE) in the log scale. To compare fluorescent Pseudomonas levels in soils prior to planting to those after the first cycle, subsample was treated as a random variable. For analyses of numbers of root- and soil-associated fluorescent Pseudomonas, Cone-tainer was treated as a random variable, and root and soil numbers were analyzed separately for each soil (Lincoln or Ithaca). To compare percents of root- and soil-associated fluorescent Pseudomonas having each trait $(\mathrm{HCN}$, protease and phlD) the PROC MIXED procedure of SAS/STAT software was utilized with the DDFM $=\mathrm{KR}$ option in the model statement. Cone-tainer was treated as a random variable. Root or soil (Ithaca or Lincoln) data for a given trait from both soils were combined and soil was treated as a fixed effect.

RFLP analysis of phlD from root and soil isolates obtained from Lewjain, RTx433 and Redlan grown in two soils

Pseudomonas isolates chosen for restriction fragment length polymorphism (RFLP) analysis of the phlD gene are indicated in Table 1 under "RFLP". Included in the analyses were the previously characterized biocontrol strains Pf-5 (genotype A), obtained from NCAUR, and P. fluorescens isolate Q2-87 (genotype B) and Pseudomonas brassicacearum isolate Q8r1-96 (Loper et al. 2012) (genotype D), kind gifts from M. Mazzola and L. Thomashow, respectively. DNA was extracted from each isolate as previously described (Funnell-

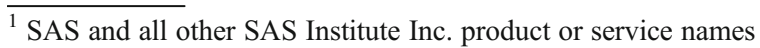
are registered trademarks or trademarks of SAS Institute Inc. in the USA and other countries. ${ }^{\circledR}$ indicates USA registration.
}

Harris et al. 2010) or, for a few recalcitrant isolates, using the MOBIO UltraClean Microbial DNA Isolation Kit (MOBIO Laboratories, Inc., Carlsbad, CA, USA). PCR amplifications of a fragment of the phlD gene from $1 \mu$ of diluted DNA were carried out in $50 \mu$ volumes using 2.5 units of AmpliTaq Gold ${ }^{\circledR}$ (Applied Biosystems, Branchburg, NJ) with 1 X Buffer II, $1.5 \mathrm{mM} \mathrm{MgCl}_{2}, 100 \mu \mathrm{M}$ of each dNTP $\left(\right.$ GeneAmp ${ }^{\circledR}$ dNTP Blend, Life Technologies, Grand Island, NY) and 10 pmole primers B2BF and BPR4 (McSpadden Gardener and Weller 2001). Reaction conditions were $94{ }^{\circ} \mathrm{C}$ for $5 \mathrm{~min}$., then 35 cycles of $94{ }^{\circ} \mathrm{C}$ for $1 \mathrm{~min}$., $55^{\circ} \mathrm{C}$ for $45 \mathrm{~s}$ and $72{ }^{\circ} \mathrm{C}$ for $1 \mathrm{~min}$., followed by an extension at $72{ }^{\circ} \mathrm{C}$ for $7 \mathrm{~min}$. Presence of a single band from each reaction was confirmed by size-fractionation on $2 \%$ agarose gels made with $0.5 \mathrm{X}$ tris-borate-EDTA (TBE) and visualization by staining with ethidium bromide (EtBr). Occasionally, quantity of the PCRamplified DNA was inadequate for conducting restriction digests. In these cases, the amplified product was purified and concentrated using Amicon Ultra-0.5 Filter Devices (Millipore, Billerica, MA) and $1 \mu$ l of the eluent was subjected to amplification using the reaction and conditions described above.

Restriction digests were conducted using 240 ng DNA for each reaction in $10 \mu \mathrm{l}$ volume. Reactions with HaeIII and MspI were carried out according to manufacturers' recommendations while reactions with $\mathrm{Taq}^{\alpha} \mathrm{I}$ were carried out at $60^{\circ} \mathrm{C}$ with $1 \mathrm{X}$ bovine serum albumin added. Restriction enzymes were purchased from New England Biolabs (NEB; Ipswich, MA). Digested DNA was size-fractionated in $3 \%$ agarose $(10 \mathrm{~cm}$ by $15 \mathrm{~cm})$ gels [2\% UltraPure ${ }^{\mathrm{TM}}$ Agarose (Invitrogen, Carlsbad, CA, USA) with $1 \%$ Certified ${ }^{\text {TM }}$ PCR Low Melt Agarose (Bio-Rad Laboratories, Hercules, CA, USA)], prepared with $0.5 \mathrm{X}$ TBE, for $90 \mathrm{~min}$. at 40 milliamps. Digested DNA was visualized by staining with $\mathrm{EtBr}$ and a digital image was created and band-sizes estimated, using the BioRad ChemiDoc XRS + molecular imager with BioRad Image Lab v. 3.0 imaging software. To determine phlD genotypes, RFLP patterns were compared with those of the three biocontrol strains and with others previously described (McSpadden Gardener and Weller 2001; Landa et al. 2002).

To confirm genotypes of four isolates that were ambiguous following RFLP analysis of phlD, amplified ribosomal DNA restriction analysis (ARDRA) was performed. Included were strains Pf-5 (ARDRA genotype A) and Q2-87 (ARDRA genotype B). Reaction mixtures 
were prepared as described above except using primers $8 \mathrm{~F}$ and 1492R (McSpadden Gardener et al. 2000) and conditions were as follows: a 5 -min incubation at $94{ }^{\circ} \mathrm{C}$ then 40 cycles of $94{ }^{\circ} \mathrm{C}$ for $30 \mathrm{~s}, 56^{\circ} \mathrm{C}$ for $45 \mathrm{~s}$ and $72^{\circ} \mathrm{C}$ for $2 \mathrm{~min}$, then after cycling, an additional 7-min extension at $72{ }^{\circ} \mathrm{C}$. Restriction digests were performed using the enzymes AluI, RsaI, Hinf1, DdeI and the double digest HaeIII with HhaI. All enzymes were purchased
Table 1 Fluorescent Pseudomonas isolates used in this study

Isolates collected from roots or soil of individual plants of wheat cultivar Lewjain (L), and sorghum cultivars Redlan (R) and RTx433 (T), grown in numbered Cone-tainers for 4 weeks. At the end of 4 weeks (cycle 1) roots and soil from randomly chosen Cone-tainers were sampled for fluorescent

Pseudomonas spp.

(see "Materials and Methods"). Soil in remaining Cone-tainers was replanted with the same plant species and cultivar (cycle 2). A total of four cycles $(1,2,3$ and 4) were conducted

a Detection $(+)$ or absence $(-)$ of hydrogen cyanide $(\mathrm{HCN})$ production, extracellular protease activity and of the phlD gene are indicated

b" $X$ " indicates that isolate was used in restriction fragment length polymorphism (RFLP) analysis of $p h l D$ gene or in the fungal inhibition assays (FIA)

${ }^{\mathrm{c}}$ The first part of the isolate number indicates field from which soil was obtained [Havelock in Lincoln, NE $(\mathrm{H})$ and Mead, near Ithaca, NE (M)] and year soil was collected. The second part indicates the Cone-tainer number from which roots (R) or soil (S) was obtained. The third part is the number assigned the isolate from those collected

\begin{tabular}{|c|c|c|c|c|c|c|c|c|}
\hline \multirow[t]{2}{*}{ Isolate $^{a}$} & \multirow[t]{2}{*}{ Cycle } & \multirow[t]{2}{*}{ Plant } & \multirow[t]{2}{*}{ Sample } & \multicolumn{3}{|l|}{ Trait $^{\mathrm{b}}$} & \multicolumn{2}{|c|}{ Analysis $^{\mathrm{c}}$} \\
\hline & & & & $\mathrm{HCN}$ & Protease & phlD & RFLP & FIA \\
\hline
\end{tabular}

Soil from Lincoln, NE

H08-1S-12 2

H08-15R-13 4

$\mathrm{R}$

Soil

H08-15S-9 4

H08-18R-6 2

H08-18R-14 2

H08-21R-8 4

H08-23S-10 1

H08-24S-3 1

H08-25S-8 2

H08-27R-9 4

H08-27S-4 4

H08-28R-14 1

H08-30R-6 4

H08-30R-13 4

H08-38S-10 2

H08-47R-5 3

H08-57R-2 3 T

H08-63R-15 4 T

H08-63S-10 4 T

H08-67R-4 4 T

H08-82R-10 2 T

Soil from Ithaca, NE

M07-3R-3 2

M07-14S-2 4

M07-21R-1 2

M07-21R-9 2

M07-30S-3 4

M07-31S-1 2

M07-42R-1 3

M07-53S-4 2 R

M07-53S-5 2 R

M07-63S-9 4 T

M07-72R-1 $3 \quad \mathrm{~T}$

M07-72R-2 3 T

M07-77R-8 2 T

M07-80R-10 2 T

M07-81R-1 $3 \quad$ T

$\begin{array}{lll}+ & & \mathrm{X} \\ + & \mathrm{X} & \mathrm{X} \\ + & \mathrm{X} & \mathrm{X} \\ + & \mathrm{X} & \mathrm{X} \\ + & \mathrm{X} & \mathrm{X} \\ + & \mathrm{X} & \mathrm{X} \\ + & \mathrm{X} & \mathrm{X} \\ + & \mathrm{X} & \\ + & \mathrm{X} & \\ + & & \mathrm{X} \\ + & \mathrm{X} & \mathrm{X} \\ + & \mathrm{X} & \mathrm{X} \\ + & \mathrm{X} & \\ + & \mathrm{X} & \\ + & \mathrm{X} & \\ + & \mathrm{X} & \\ + & \mathrm{X} & \mathrm{X} \\ + & \mathrm{X} & \mathrm{X} \\ + & & \mathrm{X} \\ + & \mathrm{X} & \mathrm{X} \\ + & & \mathrm{X}\end{array}$

$\begin{array}{ccc}+ & \mathrm{X} & \\ + & \mathrm{X} & \\ + & \mathrm{X} & \\ + & \mathrm{X} & \\ + & \mathrm{X} & \mathrm{X} \\ + & \mathrm{X} & \\ + & & \mathrm{X} \\ + & & \mathrm{X} \\ + & & \mathrm{X} \\ + & & \mathrm{X} \\ + & & \mathrm{X} \\ + & & \mathrm{X} \\ + & & \mathrm{X} \\ + & \mathrm{X} & \mathrm{X} \\ + & \mathrm{X} & \end{array}$


from Invitrogen except HaeIII, which was purchased from NEB. Restriction digests were performed according to manufacturers's instructions; the Invitrogen buffer was used in the HaeIII/HhaI digest. DNA was sizefractionated in $2 \%$ agarose gels and visualized as described above.

Co-culturing of fluorescent Pseudomonas isolates with sorghum fungal pathogens

Bacterial isolates tested against fungal pathogens are listed in Table 1 under FIA (fungal inhibition assay). Included were Q8r1-96 and Escherichia coli Rosetta ${ }^{\mathrm{TM}}$ (Novagen ${ }^{\circledR}$, EMD Chemicals, Inc. Gibbstown, NJ). Fungal isolates were the charcoal rot pathogen M. phaseolina (MP01-001, a kind gift from G. Odvody), the grain mold and stalk rot pathogens, Fusarium verticillioides (Sacc.) Nirenberg 1976 (M-1141, purchased from Fusarium Research Center, Penn State University, University Park, PA) and Fusarium thapsinum Klittich, J.F. Leslie, P.E. Nelson \& Marasas 1997 (H03-11-9), and the grain mold pathogens A. alternata (H02-755S) and C. lunata (LP09-01; a kind gift from L. Prom).

A preliminary test using Q8r1-96 and F. verticillioides was conducted on three media: one-half strength potato dextrose agar (PDA; prepared with potato dextrose broth, BD) nutrient broth (SA) yeast extract (Fisher, Fair Lawn, NJ) agar and one-half strength tryptic soy (BD) agar. Whether considering challenge by the bacterium or the water control, the fungus grew significantly better, as measured by radial growth, on PDA than the other two media $(P \leq 0.01)$. Thus, the conditions of the experiment were designed to favour fungal growth.

The experiments were conducted in the following way. Each bacterial isolate was grown overnight at room temperature in Kings B broth without antibiotics. Bacteria were washed by pelleting the cells by centrifugation $\left(5,100 \times \mathrm{g}\right.$ at $4{ }^{\circ} \mathrm{C}$ for $\left.15 \mathrm{~min}\right)$, resuspending in sterile purified water and pelleting again by centrifugation. The cells were resuspended in sterile purified water and cells $\mathrm{ml}^{-1}$ was estimated by determining $\mathrm{A}_{600}$ spectrophotometrically. Cells were diluted to $2 \times 10^{10}$ colony forming units (cfu) per ml. The medium, PDA, was prepared in $60-\mathrm{mm}$ Petri dishes. Five $\mu \mathrm{l}$ of a bacterial suspension was spotted $2 \mathrm{~mm}$ from one edge, while $5 \mu \mathrm{l}$ of sterile purified water was spotted $2 \mathrm{~mm}$ from the opposite edge. The plates were incubated at $28{ }^{\circ} \mathrm{C}$ for $48 \mathrm{~h}$, at which time the centre of the plate was inoculated with a 3-mm diameter agar plug with actively-growing fungal mycelia, taken from the edge of a three-day-old PDA culture grown at room temperature. The plates continued to be incubated at $28^{\circ} \mathrm{C}$ for 3 days. The plates were scored under a dissecting microscope, by determining the radial growth (distance from the mycelial edge of the fungal colony to the centre of the plate) on the bacterial side and the water side of the plate.

Bacterial isolates obtained from sorghum cv. Redlan (roots or soil) were tested as a group (14 isolates) and bacterial isolates obtained from cv. RTx 433 were tested as a group (10 isolates), along with Q8r1-96 and E. coli, by co-inoculating with each fungus in separate assays. For each assay, four PDA plates were inoculated with each bacterial isolate and each assay was conducted twice. Mean differences between fungal radial growth on the bacterial side versus the water side were calculated and compared against mean differences in radial growth on $E$. coli-fungal co-cultures, using the contrast function in the PROC MIXED procedure of SAS/STAT software ${ }^{\circledR}$ (SAS 2002-2008). For a given fluorescent pseudomonad, if the difference was greater than that of the $E$. coli co-culture, and $0.06 \leq P \leq 0.15$, then "+" was assigned. If the mean difference in radial growth due to a fluorescent pseudomonad was greater than that of $E$. coli, and $P \leq 0.05$, "++" was assigned. Comparisons also were made with mean radial growths on the water side of the co-cultures with fluorescent Pseudomonas isolates with that of co-cultures with $E$. coli, again, using the contrasts function in the PROC MIXED procedure, to assess whether the presence of the pseudomonad affected the radial growth of the fungus at a distance (approximately 28 or more $\mathrm{mm}$ ). When radial growth was significantly less $(P \leq 0.05)$ than those of the water side of $E$. coli co-cultures, "+++" was assigned. If there was no indication that a fluorescent pseudomonad was significantly inhibiting growth of the fungus, (i.e. none of the above situations were true), then "-" was assigned.

Phylogenetic analysis of phlD genes

A portion of the phlD gene was amplified from fluorescent Pseudomonas isolates obtained from sorghum in this study as well as Pf-5, Q2-87 and Q8r1-96 using primers $\mathrm{B} 2 \mathrm{BF}$ and BPR4 and the conditions described above. For one isolate (H08-63R-10) primers Phl2a and Phl2b (Raaijmakers and Weller 2001) also were utilized as previously described (Funnell-Harris et al. 2010). Amplification products were sequenced and contigs 
were assembled using Sequencher 4.10.1 (Gene Codes Corp., Ann Arbor, MI). Sequences were deposited in GenBank $^{\circledR}$, accessions numbers JX840717-JX840724.

Assembled sequences were compared with those in GenBank using megablast. phlD sequence corresponding to bases 6769615 to 6770221 of the complete genome sequence of Pf-5 (Accession CP000076), as well as previously-published sequences from P. fluorescens (accessions AY928635, GU181357 and GU984569), Pseudomonas sp. (accession AB636682) and Pseudomonas brassicacearum subsp. brassicacearum (accession CP002585) were compared with those from sorghum root and soil isolates using phylogenetic analysis. The DNA sequence alignment was performed using ClustalW function of MacVector version 12.0 (MacVector, Inc.; Cary, NC). The unrooted phylogram was constructed using the Neighbour Joining method with 1000 Bootstrap replicates; the distances were calculated using the Tamura-Nei algorithm. Gaps distributed proportionally and nodes with bootstrap confidence values less than $65 \%$ were collapsed.

\section{Results}

Growth chamber sorghum and wheat seedling cycling

Mean numbers of fluorescent Pseudomonas spp. were $3.98 \times 10^{3} \mathrm{cfug}^{-1}$ and $1.67 \times 10^{4} \mathrm{cfug}^{-1}$ in freshly collected soil from sorghum fields at Ithaca and Lincoln, respectively. After one cycle of planting the wheat cultivar or either sorghum cultivar, pseudomonad cfu did not significantly change except for the wheat cultivar Lewjain planted in Lincoln soil, which showed a nearly 8 -fold decline in cfu relative to the starting point $\left(2.15 \times 10^{3} \mathrm{cfug}^{-1}\right.$ soil; $\left.P=0.05\right)$. Mean numbers of fluorescent Pseudomonas isolates obtained throughout cycling were higher from roots and soil of the sorghum cultivars than the wheat cultivar (Table 2). During cycling in soil obtained at Lincoln, numbers of fluorescent Pseudomonas $\mathrm{cfug}^{-1}$ of roots or soil increased significantly from cycle 1 to cycle 4 , for all three plant genotypes $(P \leq 0.01)$. However, there was no distinct pattern for pseudomonad numbers during the trial conducted in soil obtained from Ithaca.

Production of $\mathrm{HCN}$ and extracellular protease, and the presence of the phlD gene, were determined for fluorescent Pseudomonas isolates. Soil $\times$ genotype interactions were significant for percent $\mathrm{HCN}$-producing soil isolates and extracellular protease-producing root and soil isolates $(P<0.01)$; thus results using each soil are presented separately (Table 3). For soil isolates, planting of RTx433 resulted in lower percentage of $\mathrm{HCN}$ producers in Lincoln soil, but greater percentages of protease producers when planted in Ithaca soil, when compared with plantings of Redlan or the wheat cultivar, Lewjain. For presence of the phlD gene, there were no significant differences among soil isolates from plants grown in either Ithaca or Lincoln soil $(P \geq 0.16)$. For root isolates, the only significant differences observed were in those obtained from Redlan roots, which had significantly lower percentages of protease producers than isolates obtained from RTx433 and Lewjain, when grown in Ithaca soil $(P<0.01)$. There were no significant differences in percentages of $\mathrm{HCN}$ producers or those with $p h l D$, between plants grown in each soil $(P \geq 0.30)$.

RFLP analysis of phlD from root and soil isolates obtained from Lewjain, RTx433 and Redlan grown in two soils

Genotyping results from RFLP analysis of phlD have been shown to correspond with those from non-phlD-

Table 2 Mean numbers of fluorescent Pseudomonas isolates obtained from roots and soil, when wheat cultivar Lewjain, and sorghum cultivars RTx433 and Redlan were planted for four 4week cycles in two soils (Ithaca and Lincoln, NE)

\begin{tabular}{|c|c|c|c|c|}
\hline \multirow{3}{*}{$\begin{array}{l}\text { Plant } \\
\text { genotype }\end{array}$} & \multicolumn{4}{|l|}{ Soils } \\
\hline & \multicolumn{2}{|l|}{ Ithaca } & \multicolumn{2}{|l|}{ Lincoln } \\
\hline & $\begin{array}{l}\text { Roots } \\
\left(\text { cfug }^{-1}\right)\end{array}$ & $\begin{array}{l}\text { Soil } \\
\left(\text { cfug }^{-1}\right)\end{array}$ & $\begin{array}{l}\text { Roots } \\
\left(\text { cfug }^{-1}\right)\end{array}$ & $\begin{array}{l}\text { Soil } \\
\left(\mathrm{cfug}^{-1}\right)\end{array}$ \\
\hline Lewjain & $2.00 \times 10^{4} \mathrm{a}^{\mathrm{a}}$ & $2.51 \times 10^{3} \mathrm{a}$ & $4.76 \times 10^{4} \mathrm{a}$ & $4.96 \times 10^{3} \mathrm{a}$ \\
\hline RTx433 & $5.07 \times 10^{4} \mathrm{~b}$ & $4.51 \times 10^{3} \mathrm{~b}$ & $2.59 \times 10^{5} b$ & $1.41 \times 10^{4} b$ \\
\hline Redlan & $2.94 \times 10^{4} \mathrm{c}$ & $1.38 \times 10^{4} \mathrm{c}$ & $1.29 \times 10^{5} \mathrm{c}$ & $1.65 \times 10^{4} \mathrm{~b}$ \\
\hline
\end{tabular}

Plants were grown in individual Cone-tainers. At the end of each 4-week cycle, roots and soil were collected from seven randomly-chosen cones for each genotype. Fluorescent Pseudomonas numbers were determined by dilution plating root and soil suspensions onto King's B agar amended with antibiotics. Remaining cones were re-planted with the same plant genotype

${ }^{\text {a }}$ Proc GLIMMIX was used to determine least squares means by transforming measurements into natural logs and analyzing transformed numbers. Back-transformed numeric means are reported here for ease to the reader. Comparisons of numbers of fluorescent Pseudomonas isolates from each plant genotype from either roots or soil are indicated; numbers significantly different at $P \leq 0.05$ are indicated by different letters 
Table 3 Percent of fluorescent Pseudomonas isolates, obtained from roots or soil of a wheat cultivar (Lewjain), or two sorghum cultivars (RTx433 or Redlan), cycled in two soils (Ithaca and Lincoln), with the ability to produce hydrogen cyanide (HCN) or extracellular protease, or having the phlD gene for 2,4-diacetylphloroglucinol production

\begin{tabular}{lllll}
\hline \multirow{2}{*}{$\begin{array}{l}\text { Plant } \\
\text { Isolate source }\end{array}$} & $\begin{array}{l}\text { Percent fluorescent } \\
\text { Pseudomonas isolates with: }\end{array}$ \\
\cline { 3 - 5 } & & HCN & Protease & phlD \\
\hline Ithaca soil & & & & \\
Lewjain & Roots & $3.2 \mathrm{a}^{\mathrm{a}} \pm 3.6$ & $52.9 \mathrm{a} \pm 6.2$ & $2.2 \mathrm{a} \pm 1.1$ \\
RTx433 & Roots & $1.5 \mathrm{a} \pm 3.4$ & $62.4 \mathrm{a} \pm 5.9$ & $3.8 \mathrm{a} \pm 1.1$ \\
Redlan & Roots & $0.7 \mathrm{a} \pm 3.4$ & $19.0 \mathrm{~b} \pm 5.8$ & $3.2 \mathrm{a} \pm 1.0$ \\
Lewjain & Soil & $0.0 \mathrm{a} \pm 2.9$ & $35.9 \mathrm{a} \pm 4.6$ & $2.3 \mathrm{a} \pm 0.9$ \\
RTx433 & Soil & $4.9 \mathrm{a} \pm 3.1$ & $59.0 \mathrm{~b} \pm 5.0$ & $0.4 \mathrm{a} \pm 1.0$ \\
Redlan & Soil & $1.8 \mathrm{a} \pm 2.9$ & $23.6 \mathrm{a} \pm 4.6$ & $2.2 \mathrm{a} \pm 0.9$ \\
Lincoln soil & & & \\
Lewjain & Roots & $27.4 \mathrm{a} \pm 3.4$ & $45.6 \mathrm{a} \pm 5.8$ & $1.4 \mathrm{a} \pm 1.0$ \\
RTx433 & Roots & $24.8 \mathrm{a} \pm 3.4$ & $50.5 \mathrm{a} \pm 5.9$ & $1.7 \mathrm{a} \pm 1.1$ \\
Redlan & Roots & $24.0 \mathrm{a} \pm 3.4$ & $48.2 \mathrm{a} \pm 5.8$ & $1.8 \mathrm{a} \pm 1.0$ \\
Lewjain & Soil & $28.6 \mathrm{a} \pm 2.7$ & $29.1 \mathrm{a} \pm 4.3$ & $0.7 \mathrm{a} \pm 0.9$ \\
RTx433 & Soil & $16.0 \mathrm{~b} \pm 2.7$ & $25.8 \mathrm{a} \pm 4.3$ & $0.5 \mathrm{a} \pm 0.9$ \\
Redlan & Soil & $30.8 \mathrm{a} \pm 2.7$ & $29.9 \mathrm{a} \pm 4.3$ & $1.9 \mathrm{a} \pm 0.9$ \\
\hline
\end{tabular}

Individual plants were grown in Cone-tainers. At the end of each cycle, roots and soil from seven plants of each genotype were sampled and fluorescent Pseudomonas isolates were collected by spreading root or soil suspensions onto King's B agar amended with antibiotics. Isolates were screened for each of the three traits. See "Materials and Methods"

${ }^{a}$ Least squares means (LSM) were calculated and compared for each trait and soil, and for either roots or soil. LSMs and standard errors are shown. Direct comparisons of percentages of fluorescent Pseudomonas isolates obtained from either roots or soil, with a given trait, are indicated by letters; LSM with the same letter are not significantly different at $P \leq 0.05$

based genomic fingerprinting analyses (Mavrodi et al. 2001). To compare phlD genotypes of isolates obtained from sorghum and wheat grown in sorghum field soils, with wheat isolates from other studies, isolates were genotyped by PCR-amplification of a portion of the phlD gene, followed by RFLP analyses. Restriction patterns were compared with those of Pf-5 (A), Q2-87 (B) and Q8r1-96 (D) and others previously published (McSpadden Gardener and Weller 2001; Landa et al. 2002). Genotypes of four isolates were confirmed by conducting ARDRA (RFLP of amplified rDNA region) and comparing with those of Pf-5 and Q2-87 and those previously published (McSpadden Gardener et al.
2000). Results are summarized in Table 4. Most $(80 \%)$ of the tested isolates were genotype D. From seedlings grown in Ithaca soil, genotype B was found associated with roots and soil of wheat cv. Lewjain and with roots of sorghum cv. RTx433 (no soil isolates were tested). In Lincoln soil, genotypes B and I were found on roots of sorghum cv. Redlan. In general, the phlD genotypes from sorghum isolates were similar to those found in wheat and no new genotypes were detected.

\section{Co-culturing of fluorescent Pseudomonas isolates with sorghum fungal pathogens}

Fluorescent Pseudomonas spp. isolates from sorghum seedlings (14 isolates from Redlan and 10 isolates from RTx433) were individually co-cultured with five fungal pathogens: A. alternata, C. lunata, F. thapsinum, $F$. verticillioides and M. phaseolina. Pseudomonas brassicacearum, Q8r1-96, was included in assays as the positive control. Mean differences in fungal radial growth were determined between each Pseudomonas sp.-fungus combination and the water control and compared with the mean difference from co-culturing the same fungus with the negative control, $E$. coli (Rosetta). If inhibition by the fluorescent pseudomonad was modest $(0.06 \leq P \leq$ $0.15)$ then "+" is indicated in Table 5. If the inhibition was moderate $(P \leq 0.05)$, then " ++ " is indicated in Table 5. For some pseudomonad treatments, fungal growth was inhibited on both sides of the agar medium, suggesting that a factor diffused, resulting in inhibition at a distance from the Pseudomonas inoculum (Janisiewicz and Roitman 1988). In these cases, the mean differences between fungal radial growth on the two sides of the plates was small. Therefore, mean fungal radial growth for the water controls associated with each Pseudomonas co-culture were compared with the mean fungal radial growth for the water control of the E. coli co-cultures; when the mean differences were significant $(P \leq 0.05)$, then "+++" was indicated in Table 5.

Interactions between Pseudomonas spp. and fungi that resulted in apparent antagonism in at least one assay are shown in Table 5. Sorghum cv. Redlan isolate H0815R-13 and RTx433 isolate H08-63R-15 exhibited growth inhibition of all fungi tested. Redlan isolates H08-15S-9, H08-18R-6, H08-18R-14, H08-21R-8, and H08-27S-4, and RTx433 isolates H08-63S-10, H08-67R-4 and M07-77R-8 also inhibited growth of most of the sorghum fungi tested. Most of these fluorescent Pseudomonas spp. were obtained from roots or 
Table 4 Genotypes of $p h l D^{+}$fluorescent Pseudomonas isolates, obtained from roots and soil of seedlings of a wheat cultivar, Lewjain, and sorghum cultivars RTx433 and Redlan, grown in two soils, as determined by PCR-RFLP analyses of a portion of the $p h l D$ gene

\begin{tabular}{|c|c|c|c|c|}
\hline \multirow[t]{3}{*}{ Plant } & \multicolumn{4}{|l|}{ Field soil $^{\mathrm{a}}$} \\
\hline & \multicolumn{2}{|l|}{ Ithaca } & \multicolumn{2}{|l|}{ Lincoln } \\
\hline & Roots & $\begin{array}{l}\text { Cone-tainer } \\
\text { soil }\end{array}$ & Roots & $\begin{array}{l}\text { Cone-tainer } \\
\text { soil }\end{array}$ \\
\hline Lewjain & $\mathrm{B}(1)^{\mathrm{b}} \mathrm{D}(2)$ & B (1) & $\mathrm{D}(3)$ & $\mathrm{D}(1)$ \\
\hline RTx433 & B (1) D (1) & $\mathrm{nt}^{\mathrm{c}}$ & $\mathrm{D}(3)$ & $\mathrm{nt}$ \\
\hline Redlan & nt & $\mathrm{D}(2)$ & $\begin{array}{l}\text { B (1) D } \\
\text { (3) I (1) }\end{array}$ & $\mathrm{D}(5)$ \\
\hline
\end{tabular}

Fluorescent Pseudomonas isolates were collected from roots and soil of individual seedlings grown in Cone-tainers for four 4-week cycles, at the end of each cycle. $p h l D^{+}$isolates were chosen for PCR-RFLP. A portion of phlD was amplified and the products were digested using three different restriction enzymes and size-fractionated; the resulting patterns were compared with previously-published genotypes (See "Materials and Methods"). To confirm discrimination of genotypes of four isolates, amplified ribosomal DNA restriction analysis was also performed

${ }^{a}$ Field soils were obtained from post-harvest sorghum fields located at Ithaca and Lincoln, NE

${ }^{\mathrm{b}}$ Number in parentheses indicates number of isolates with given genotype

c "nt" indicates "not tested"

soil of sorghum seedlings grown in Lincoln soil (prefix "H08"). Four Redlan isolates (not listed in Table 5) failed to exhibit potential antagonism to any of the five fungi. Many of the sorghum fluorescent Pseudomonas isolates inhibited the growth of the fungus $C$. lunata in at least one assay ( $75 \%$ of the isolates tested; Table 5), whereas $F$. thapsinum and $F$. verticillioides were inhibited by half the isolates or fewer ( $45.8 \%$ and $50 \%$, respectively).

Phylogenetic analysis of phlD sequences

Sorghum isolates representing the different phlD genotypes, determined using RFLP analyses, and isolates exhibiting significant inhibition of most of the sorghum fungal pathogens, were chosen for sequence analysis of a portion of the phlD gene. Most sequences from isolates analyzed (M07-80R-10, H08-21R-8, H08-27S-4, H08-28S-14, H08-63R-15, H08-63S-10, H08-67R-4) were highly similar (99\%) to phlD from P. fluorescens isolates previously published while one sequence (H0821R-6) had lower similarity (93\%). Using phylogenetic analysis, sequences from sorghum isolates were compared with those from Pf-5, Q8r1-96 and Q2-87 and phlD sequences available in GenBank. The results indicated that sequences from the sorghum soil and root isolates analyzed were similar to Q2-87, Q8r1-96, two other P. fluorescens (accessions GU984569 and AY928635) isolates and another $P$. brassicacearum (subsp. brassicacearum) (CP002585) and in a different clade than Pf-5 phlD sequence (Fig. 1). Isolate M07-80R10 was most similar to Q2-87 and another $P$. fluorescens isolate while all other sorghum root and soil isolates were most similar to one-another, to Q8r1-96 and another P. fluorescens isolate, and to P. brassicacearum subsp. brassicacearum.

\section{Discussion}

Fluorescent Pseudomonas spp. were collected from roots and soil of sorghum cultivars Redlan and RTx433, and one wheat cultivar (Lewjain), that were "cycled" by growing seedlings in soil for 4-week cycles. Two assays were conducted using different soils. Pseudomonas spp. were characterized for the presence of $p h l D$, a gene in the operon that specifically confers the ability to produce 2,4DAPG (Bangera and Thomashow 1999). Isolates were also screened for production of $\mathrm{HCN}$ and extracellular protease. Sorghum isolates with the phlD gene, many with at least one of the other two traits, were further characterized by RFLP analysis of a portion of phlD, and compared with previously characterized genotypes (McSpadden Gardener and Weller 2001; Landa et al. 2002) and those of the wheat isolates from this study. Inhibition assays using $p h l D^{+}$sorghum isolates, challenging growth of five sorghum pathogens, also were conducted. It was found that at least two fluorescent Pseudomonas isolates, one isolated from each sorghum cultivar, exhibited traits characteristic of biological control strains, including the phlD genotype of superior root colonizers.

Of the over 3,500 fluorescent Pseudomonas root and soil isolates screened, two $p h l D^{+}$isolates from sorghum, H08-15R-13 and H08-63R-15, are promising candidates for biological control and warrant further investigation to determine their potential in cropping systems. It is not known whether 2,4-DAPG or other undetermined traits are involved with antagonism towards the sorghum fungal pathogens screened in this analysis. To determine the efficacy of these two isolates as biological 
Table 5 Inhibition of sorghum fungal pathogens following coinoculation with fluorescent Pseudomonas isolates obtained from sorghum seedlings, as compared with co-inoculation with
Escherichia coli, and comparing effects of both bacteria on fungal growth with water controls

\begin{tabular}{|c|c|c|c|c|c|c|c|c|c|c|}
\hline \multirow{2}{*}{$\begin{array}{l}\text { Fungi } \\
\text { Assay \# }\end{array}$} & \multicolumn{2}{|c|}{ A. alternata } & \multicolumn{2}{|c|}{ C. lunata } & \multicolumn{2}{|c|}{ F. thapsinum } & \multicolumn{2}{|c|}{ F. verticillioides } & \multicolumn{2}{|c|}{ M. phaseolina } \\
\hline & 1 & 2 & 1 & 2 & 1 & 2 & 1 & 2 & 1 & 2 \\
\hline \multicolumn{11}{|c|}{ A. Assays using isolates from Redlan $\operatorname{root}(\mathrm{R})$ and soil $(\mathrm{S})^{\mathrm{a}}$} \\
\hline Type 3 test of fixed effects ${ }^{b}$ : & $<0.01$ & $<0.01$ & $<0.01$ & $<0.01$ & 0.03 & $<0.01$ & $<0.01$ & $<0.01$ & $<0.01$ & $<0.01$ \\
\hline H08-15R-13 & +++ & +++ & +++ & +++ & ++ & ++ & +++ & +++ & +++ & +++ \\
\hline H08-15S-9 & - & +++ & +++ & +++ & - & + & +++ & - & +++ & +++ \\
\hline H08-18R-6 & - & +++ & +++ & +++ & ++ & + & - & +++ & +++ & +++ \\
\hline H08-18R-14 & +++ & +++ & +++ & +++ & + & ++ & - & - & +++ & +++ \\
\hline H08-21R-8 & - & - & ++ & ++ & ++ & ++ & +++ & +++ & +++ & +++ \\
\hline H08-27R-9 & - & - & ++ & +++ & - & + & +++ & - & +++ & - \\
\hline H08-27S-4 & + & +++ & +++ & +++ & + & - & +++ & +++ & +++ & +++ \\
\hline H08-28S-14 & - & + & - & - & ++ & - & - & - & - & - \\
\hline M07-42R-1 & - & - & - & ++ & - & - & - & - & - & - \\
\hline Q8r1-96 & ++ & +++ & +++ & +++ & - & +++ & +++ & - & +++ & +++ \\
\hline \multicolumn{11}{|c|}{ B. Assays using isolates from $\mathrm{RT} \times 433$ root $(\mathrm{R})$ and soil $(\mathrm{S})^{\mathrm{a}}$} \\
\hline Type 3 test of fixed effects ${ }^{b}$ : & $<0.01$ & $<0.01$ & $<0.01$ & $<0.01$ & 0.09 & 0.65 & 0.02 & $<0.01$ & $<0.01$ & $<0.01$ \\
\hline H08-57R-2 & - & - & ++ & - & - & - & - & - & - & - \\
\hline H08-63R-15 & ++ & +++ & +++ & +++ & +++ & + & +++ & +++ & +++ & +++ \\
\hline H08-63S-10 & ++ & +++ & +++ & ++ & - & - & +++ & +++ & +++ & ++ \\
\hline H08-67R-4 & ++ & +++ & +++ & +++ & - & - & +++ & +++ & ++ & +++ \\
\hline H08-82R-10 & - & - & ++ & - & - & - & - & - & - & - \\
\hline M07-63S-9 & - & ++ & ++ & - & - & - & - & - & ++ & - \\
\hline M07-72R-1 & - & ++ & ++ & - & - & - & - & - & ++ & - \\
\hline M07-72R-2 & - & ++ & - & - & - & - & - & - & ++ & - \\
\hline M07-77R-8 & ++ & ++ & ++ & - & +++ & - & $\mathrm{nt}^{\mathrm{c}}$ & +++ & ++ & - \\
\hline M07-80R-10 & + & + & ++ & - & - & - & - & + & - & - \\
\hline Q8R1-96 & ++ & ++ & +++ & +++ & +++ & +++ & ++ & +++ & +++ & ++ \\
\hline
\end{tabular}

Sorghum fungal pathogens were co-cultured with a fluorescent Pseudomonas isolate from roots or soil of sorghum cultivar Redlan or RTx433, the biological control isolate Q8r1-96 or E. coli Rosetta. On the opposite side of the agar medium from the bacterial suspension, a water control was plated (see "Materials and Methods"). Mean difference in radial growth of fungus due to fluorescent pseudomonad versus water control was compared with mean difference in radial growth due to $E$. coli versus water using the contrast function in the PROC MIXED procedure of SAS/STAT software (SAS 2002-2008). When difference in measurements from fluorescent pseudomonad was greater than that of $E$. coli, and $0.06 \leq P \leq 0.15$, then "+" was assigned. If difference of measurement from fluorescent pseudomonad was greater than that of $E$. coli, and $P \leq 0.05$, "++" was assigned. Comparisons also were made with radial growth of water-side of the co-culture with fluorescent Pseudomonas isolate with that of co-culture with E. coli. When radial growth was significantly less $(P \leq 0.05)$ than that on $E$. coli co-culture, "+++" was assigned. If there was no indication that a fluorescent pseudomonad was significantly inhibiting growth of the fungus, (i.e. none of the situations above were true), then "-" was assigned

${ }^{a}$ Fluorescent Pseudomonas isolates were obtained by growing sorghum cultivar Redlan or RTx433 in two soils from Havelock (H) field in Lincoln, NE, or Mead (M) field in Ithaca, NE, for four 4-week cycles. At the end of each cycle, fluorescent Pseudomonas spp. were isolated from roots and associated soil of individual plants, then tested for biological control activities of HCN and extracellular protease production, or for the presence of the phlD gene for 2,4-diacetylphloroglucinol production. Root and soil isolates from both sorghum cultivars grown in both soils, exhibiting at least one biological control activity, were chosen to determine effects on coculturing with sorghum fungal pathogens

${ }^{\mathrm{b}}$ Type 3 tests were conducted on fixed effect, which was bacterial isolate (fluorescent Pseudomonas spp. and E. coli)

c "nt" indicates "not tested" 


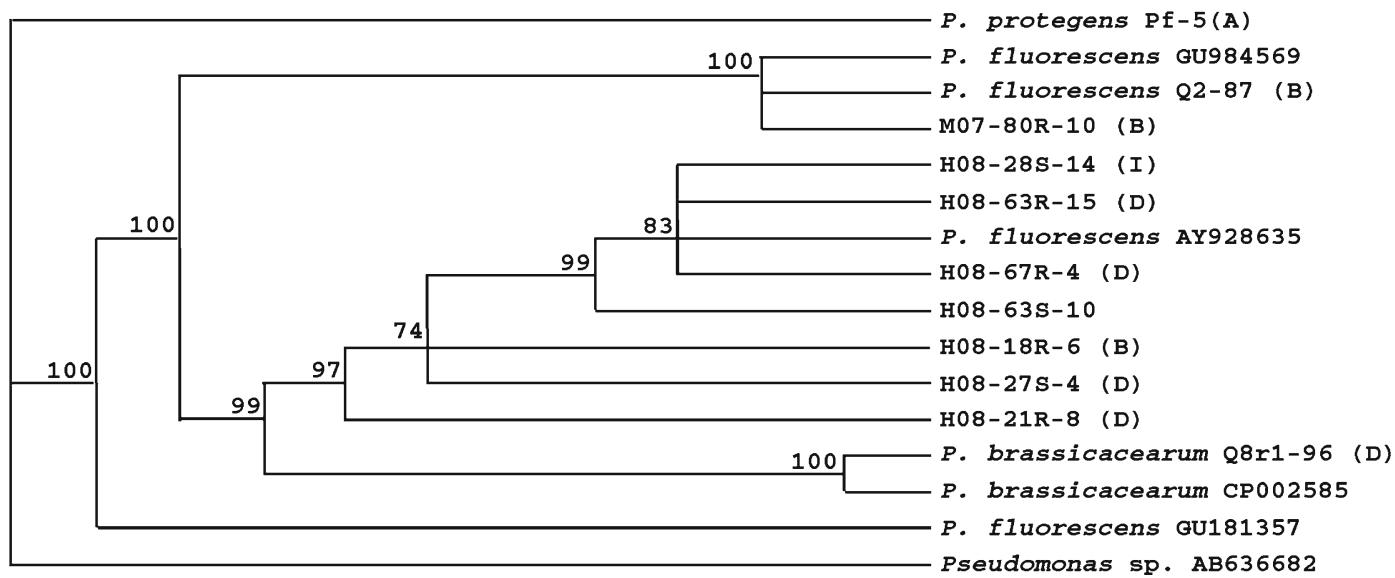

Fig. 1 Phylogenetic analysis of sequences of a portion of the phlD gene from fluorescent Pseudomonas isolates from sorghum roots and soil. Included in the analyses are biological control strains Pf-5, Q2-87 and Q8r1-96 and highly similar sequences found in GenBank ${ }^{\circledR}$; isolate numbers or GenBank

control agents, other qualities would need to be assessed, such as potential for plant growth promotion, or root colonization and competitive abilities on sorghum hybrids and other crops like maize, wheat and soybean, which are commonly found in sorghum cropping rotations (Raaijmakers and Weller 2001; Landa et al. 2002; Compant et al. 2010).

In a previous field study, in which root and soil Pseudomonas isolates were collected throughout the growing season, there were no significant differences in percentages of $\mathrm{HCN}$ soil isolates but root isolates from plants grown at Ithaca had greater numbers of HCNproducers than isolates from plants grown at Lincoln (Funnell-Harris et al. 2010). Additionally, in this previous study, $p h l D^{+}$isolates were not indicated (at $0 \%$ ) on roots and in soil of Redlan plants grown at the Lincoln field. This is in contrast to the present study in which there were significant soil effects for production of hydrogen cyanide by soil and root Pseudomonas spp. isolates (Table 3) with the percent of these isolates obtained from Lincoln soil being significantly greater than those from Ithaca soil $(P<0.01)$. On the other hand, $p h l D^{+}$ isolates were obtained from roots or soil from Redlan and RTx430 plants grown in Lincoln soils (Tables 1 and 3). In this study, seedlings were planted and cycled four times, resulting in a build-up of sorghum root material in the soil. The seedlings were grown under controlled, and relatively cool, temperature conditions and watered regularly. In the previous field study, plants were sampled from 4 weeks to maturity, there was no fresh organic accession number, respectively, follow the species name. (See "Materials and Methods") The letter in parentheses following the number designation or GenBank accession number is the phlD genotype, if known. The bootstrap values (percentage) for 1,000 replicates are indicated at each node

material added to the soil, and, while fields at Ithaca were irrigated, at Lincoln there was no additional water applied outside of rainfall (Funnell-Harris et al. 2010). In the previous field study, environment may have affected numbers and traits of fluorescent Pseudomonas isolates even though it was also clear that genotype played a role. Results of the present study, in which plants were grown in the two soils under the same controlled conditions, suggested that biotic and/or abiotic factors within the soil were contributing to the diversity of Pseudomonas isolates recovered from roots and soil in addition to plant genotype. Approximately $2 \%$ of the fluorescent Pseudomonas spp. had the correct band-size, when root and soil isolates were screened for the presence of $p h l D$ using PCR amplification. Most (62\%) of these Pseudomonas spp. had at least one of the other two traits and a small number $(8 \%)$ possessed all three traits. It previously has been proposed that when breeding for improved crop germplasm, indirect selection for plant traits that enhance association with beneficial microorganisms may also have occurred (McSpadden Gardener et al. 2005).

In the present study, fluorescent Pseudomonas genotypes also were analyzed using RFLP analyses of a fragment of the phlD gene. In Ithaca soil, two genotypes were recovered from both wheat and sorghum roots or soil, and three genotypes recovered from Lincoln soil, one from wheat and three from sorghum systems. In spite of the relatively small number of $p h l D^{+}$isolates identified, this study was fairly extensive for these soils 
and sorghum cultivars due to the large number of isolates screened. No new Pseudomonas genotypes were detected in these soils on either wheat or sorghum. Interestingly, genotype D (McSpadden Gardener and Weller 2001) was the predominant one in both wheat and sorghum systems, a genotype common among biocontrol strains with superior root colonizing capabilities (Raaijmakers and Weller 2001; Landa et al. 2002). The limited diversity of Pseudomonas genotypes associated with sorghum and wheat in each soil was consistent with previous studies in wheat (McSpadden Gardener et al. 2000; Landa et al. 2006), and other crops such as corn and soybean (McSpadden Gardener et al. 2005) or grape (Svercel et al. 2009).

Most of the pseudomonad isolates that exhibited in vitro antagonism to several sorghum fungal pathogens were obtained from Lincoln soil (Table 5). On the other hand, all of the isolates obtained from RTx 433 seedlings exhibited antagonism in at least one assay while four of the Redlan isolates (31\% of those screened) did not exhibit any antagonism during the in vitro co-culturing assays. Two Pseudomonas isolates, H08-15R-13 (from Redlan roots) and H08-63R-15 (from RTx433 roots), exhibited antagonism to the fungal pathogens in all assays and were genotype D. In general, the two Fusarium species were less sensitive to being cocultured with Pseudomonas than the other sorghum pathogens. Only two of the ten fluorescent pseudomonads screened from RTx433 seedlings exhibited antagonism to the sorghum stalk and grain pathogen, $F$. thapsinum (Table 5). Eight of 14 isolates collected from Redlan seedlings inhibited growth of this pathogen in at least one assay. However, it is possible that outcomes would be different if co-culturing was conducted on another medium (McSpadden Gardener et al. 2005).

This research illustrates the intersection between phlD genotypes of fluorescent Pseudomonas spp., plant genotype and soil characteristics, both biotic and abiotic. The soil clearly affected the composition of $\mathrm{HCN}$ producers associated with sorghum cultivars and the composition of extracellular protease producers isolated from Redlan roots $(P \leq 0.01$; Table 3$)$. Among the $p h I D$ Pseudomonas isolates identified from sorghum and wheat, genotype D dominated (Table 4), a genotype associated with "superior" root colonization and competitiveness (Weller et al. 2007). It appeared that sorghum genotype influenced the fungal inhibitory phenotypes of the isolates: more Redlan isolates were antagonistic to fungal growth than RTx433 isolates when co-cultured with $F$. thapsinum. On the other hand, a majority of the isolates from either sorghum grown in Lincoln soil showed inhibitory effects in most assays, which suggests that soil is a major factor. These observations are consistent with previous field studies, which concluded that physical and biological attributes of the soil played a significant role in determining characteristics of fluorescent Pseudomonas spp. isolated from the sorghum rhizosphere, but plant genotype also had a considerable effect (McSpadden Gardener 2007; Funnell-Harris et al. 2010).

Acknowledgments The authors thank P. O'Neill for overseeing laboratory experiments and conducting statistical analyses, J. Toy for production of greenhouse-grown seed and K. Wohlgemuth and M. Bartels for technical assistance. Mention of trade names or commercial products in this article is solely for the purpose of providing specific information and does not imply recommendation or endorsement by the U.S. Department of Agriculture. This article is in the public domain and not copyrightable. It may be freely reprinted with customary crediting of source. The U.S. Department of Agriculture (USDA) prohibits discrimination in all its programs and activities on the basis of race, color, national origin, age, disability, and where applicable, sex, marital status, familial status, parental status, religion, sexual orientation, genetic information, political beliefs, reprisal, or because all or part of an individual's income is derived from any public assistance program. (Not all prohibited bases apply to all programs.) Persons with disabilities who require alternative means for communication of program information (Braille, large print, audiotape, etc.) should contact USDA's TARGET Center at (202) 720-2600 (voice and TDD). To file a complaint of discrimination, write to USDA, Director, Office of Civil Rights, 1400 Independence Avenue, S.W., Washington, D.C. 20250-9410, or call (800) 795-3272 (voice) or (202) 720-6382 (TDD). USDA is an equal opportunity provider and employer.

\section{References}

Anderson, L. M., Stockwell, V. O., \& Loper, J. E. (2004). An extracellular protease of Pseudomonas fluorescens inactivates antibiotics of Pantoea agglomerans. Phytopathology, 94, 1228-1234.

Asif, M., Rooney, L. W., Acosta-Sanchez, D., Mack, C. A., \& Riaz, M. N. (2010). Uses of sorghum grain in gluten-free products. Cereal Foods World, 55, 285-291.

Bangera, M. G., \& Thomashow, L. S. (1999). Identification and characterization of a gene cluster for synthesis of the polyketide antibiotic 2,4-diacetylphloroglucinol from Pseudomonas fluorescens Q2-87. Journal of Bacteriology, 181, 31553163.

Castric, K. F., \& Castric, P. A. (1983). Method for rapid detection of cyanogenic bacteria. Applied and Environmental Microbiology, 45, 701-702. 
Compant, S., Clément, C., \& Sessitsch, A. (2010). Plant growthpromoting bacteria in the rhizo- and endosphere of plants: their role, colonization, mechanisms involved and prospects for utilization. Soil Biology and Biochemistry, 42, 669-678.

Cook, R. J. (2007). Management of resident plant growthpromoting rhizobacteria with the cropping system: a review of experience in the US Pacific Northwest. European Journal of Plant Pathology, 119, 255-264.

Dogget, H. (1988). Sorghum. Essex: Longman Group UK Limited.

Funnell-Harris, D. L., Pedersen, J. F., \& Marx, D. B. (2008). Effect of sorghum seedlings, and previous crop, on soil fluorescent Pseudomonas spp. Plant and Soil, 311, 173-187.

Funnell-Harris, D. L., Pedersen, J. F., \& Sattler, S. E. (2010). Soil and root populations of fluorescent Pseudomonas spp. associated with seedlings and field-grown plants are affected by sorghum genotype. Plant and Soil, 335, 439-455.

Janisiewicz, W. J., \& Roitman, H. (1988). Biological control of blue mold and gray mold on apple and pear with Pseudomonas cepacia. Phytopathology, 78, 1697-1700.

Landa, B. B., Mavrodi, O. V., Raaijmakers, J. M., McSpadden Gardener, B. B., Thomashow, L. S., \& Weller, D. M. (2002). Differential ability of genotypes of 2,4-diacetylphloroglucinol-producing Pseudomonas fluorescens strains to colonize the roots of pea plants. Applied and Environmental Microbiology, 68, 3226-3237.

Landa, B. B., Mavrodi, O. V., Schroeder, K. L., Allende-Molar, R., \& Weller, D. M. (2006). Enrichment and genotypic diversity of phlD-containing fluorescent Pseudomonas spp. in two soils after a century of wheat and flax monoculture. FEMS Microbiology Ecology, 55, 351-368.

Laville, J., Voisard, C., Keel, C., Maurhofer, M., Défago, G., \& Haas, D. (1992). Global control in Pseudomonas fluorescens mediating antibiotic synthesis and suppression of black root rot of tobacco. Proceedings of the National Academy of Sciences of the United States of America, 89, 1562-1566.

Loper, J. E., Hassan, K. A., Mavrodi, D. V., Davis, E. W., II, Lim, C. K., Shaffer, B. T., et al. (2012). Comparative genomics of plant associated Pseudomonas spp.: insights into diversity and inheritance of traits involved in multitrophic interactions. PLoS Genetics, 8, e1002784.

Mavrodi, O. V., McSpadden Gardener, B. B., Mavrodi, D. V., Bonsall, R. F., Weller, D. M., \& Thomashow, L. S. (2001). Genetic diversity of phlD from 2,4-diacetylphloroglucinolproducing fluorescent Pseudomonas spp. Phytopathology, 91, 35-43.

Mazzola, M., Funnell, D. L., \& Raaijmakers, J. M. (2004). Wheat cultivar-specific selection of 2,4-diacetylphloroglucinol-producing fluorescent Pseudomonas species from resident soil populations. Microbial Ecology, 48, 338-348.

McSpadden Gardener, B. B. (2007). Diversity and ecology of biocontrol Pseudomonas spp. in agricultural systems. Phytopathology, 97, 221-226.

McSpadden Gardener, B. B., \& Weller, D. M. (2001). Changes in populations of rhizosphere bacteria associated with take-all disease of wheat. Applied and Environmental Microbiology, 67, 4414-4425.

McSpadden Gardener, B. B., Schroeder, K. L., Kalloger, S. E., Raaijmakers, J. M., Thomashow, L. S., \& Weller, D. M. (2000). Genotypic and phenotypic diversity of phlD-containing Pseudomonas strains isolated from the rhizosphere of wheat. Applied and Environmental Microbiology, 66, 1939-1946.

McSpadden Gardener, B. B., Gutierrez, L. J., Joshi, R., Edema, R., \& Lutton, E. (2005). Distribution and biocontrol potential of $p h l D^{+}$pseudomonads in corn and soybeans fields. Phytopathology, 95, 715-724.

Nimbal, C. I., Pedersen, J. F., Yerkes, C. N., Weston, L. A., \& Weller, S. C. (1996). Phytotoxicity and distribution of sorgoleone in grain sorghum germplasm. Journal of Agricultural and Food Chemistry, 44, 1343-1347.

Raaijmakers, J. M., \& Weller, D. M. (2001). Exploiting genotypic diversity of 2,4-diacetylphloroglucinol-producing Pseudomonas spp.: characterization of superior rootcolonizing P. fluorescens strain Q8r1-96. Applied and Environmental Microbiology, 67, 2545-2554.

Ramette, A., Frapolli, M., Fischer-Le Saux, M., Gruffaz, C., Meyer, J.-M., Défago, G., et al. (2011). Pseudomonas protegens sp. nov., widespread plant-protecting bacteria producing the biocontrol compounds 2,4-diacetylphloroglucinol and pyoluteorin. Systematic and Applied Microbiology, 34, 180-188.

Sarath, G., Mitchell, R. B., Sattler, S. E., Funnell, D., Pedersen, J. F., Graybosch, R. A., et al. (2008). Opportunities and roadblocks in utilizing forages and small grains for liquid fuels. Journal of Industrial Microbiology and Biotechnology, 35, 343-354.

SAS. (2002-2008). The data analysis for this paper was generated using SAS/STAT software, version 9.2 of the SAS System for Windows. Copyright (C) 2002-2008 SAS Institute Inc. SAS and all other SAS Institute Inc. product or service names are registered trademarks of SAS Institute Inc., Cary, NC, USA.

Svercel, M., Christen, D., Moënne-Loccoz, Y., Duffy, B., \& Défago, G. (2009). Effect of long-term vineyard monoculture on rhizosphere populations of pseudomonads carrying the antimicrobial biosynthetic gene phlD and/or hcnAB. FEMS Microbiology Ecology, 68, 25-36.

Weller, D. M. (2007). Pseudomonas biocontrol agents of soilborne pathogens: Looking back over 30 years. Phytopathology, 97, 250-256.

Weller, D. M., Landa, B. B., Mavrodi, O. V., Schroeder, K. L., De La Fuente, L., Bankhead, S. B., et al. (2007). Role of the 2,4-diacetylphloroglucinol-producing fluorescent Pseudomonmonas spp. in the defense of plant roots. Plant Biology, 9, 4-20.

Williams, R. J., \& Rao, K. N. (1978). A review of sorghum grain mold. In R. J. Williams, R. A. Frederiksen, \& L. K. Mughogho (Eds.), Proceedings of the international workshop of sorghum diseases (pp. 79-92). Andhra Pradesh: ICRISAT. 